\title{
The Role of Community-Based Forest Management on the Awareness of Watershed Protection and Conservation
}

\author{
Article by Gerald T. Malabarbas and Novlloyd E. Celeste \\ Northwest Samar State University, Phillipines \\ Email: gmalabarbas@yahoo.com
}

\begin{abstract}
Watersheds play an important role in our ecological system especially to the communities surrounding it. In the Philippines, domestic, industrial water and irrigation systems were supplied by watersheds. However, not all watersheds are truly protected even though there are several community-based forest management programs implemented. Thus, this study tries to elicit the role of community-based forest management on the awareness of watershed protection and conservation.

In particular, it tries to 1) generate baseline data on the demographic, livelihood activities, resources used of the communities living within the watershed area of Calbayog Pan-as Falls Hayiban Protected Landscape (CPHPL); 2) determine the relationship of the respondents' profile to their level of awareness of watershed and to their existing watershed protection and conservation practices; and 3) recommend programs and policy that would strengthen community-based forest management protection.

The study was conducted in the five upland communities of CPHPL, namely: Sitio Pena 2, Cango-maud, Danao 2, San Rufino and Cag-anahaw. A descriptive-survey was used to assess the relationship of awareness of watershed protection and demographic profile.

Results show that educational attainment has a significant relationship (0.05\% level) to the level of awareness on watershed roles and functions in the environment among the upland communities. This is despite most of the respondents (56.5\%) have obtained primary education.

This means, awareness of existing watershed protection and conservation practices helps educate the people about watershed conservation and protection. In fact, the presence of community-based forest management program made the community moderately aware (33.2\%) about watershed protection.
\end{abstract}

Keywords: watershed, watershed protection, watershed conservation, forest

\section{Introduction}

Watersheds play an essential functional role in supplying water to every community (Postel \& Thompson, 2005).

The Pan-as Hayiban Protected Landscape (CPHPL) provides water supply in Calbayog City with an area of 7, 832 of which 5,000 Ha is deforested. PENRO reported that it is only $29 \%$ was rehabilitated which is alarming to the destruction of the watershed area that might affect the loss or shortage of water supply in the locality due to this reason.

Thus, this study tries to elicit the role of community-based forest management on the awareness of watershed protection and conservation.

\section{Methodology}

This study employed descriptive-survey method. Survey questionnaire was the primary tool used in gathering data. Questionnaire was extracted from the tools used by Habtamu (2011), Harrison (2006), and Wahab (2009). Researchers conducted schedule interview and actual field visit/observation in gathering data. Then, random sampling technique was used in calculating the sample size through the Slovin's formula. Frequency, percentage, chi-square and pearson product-moment correlation were statistical tools used in treating and interpreting data. 
South American Journal of Management

Special Edition 2016

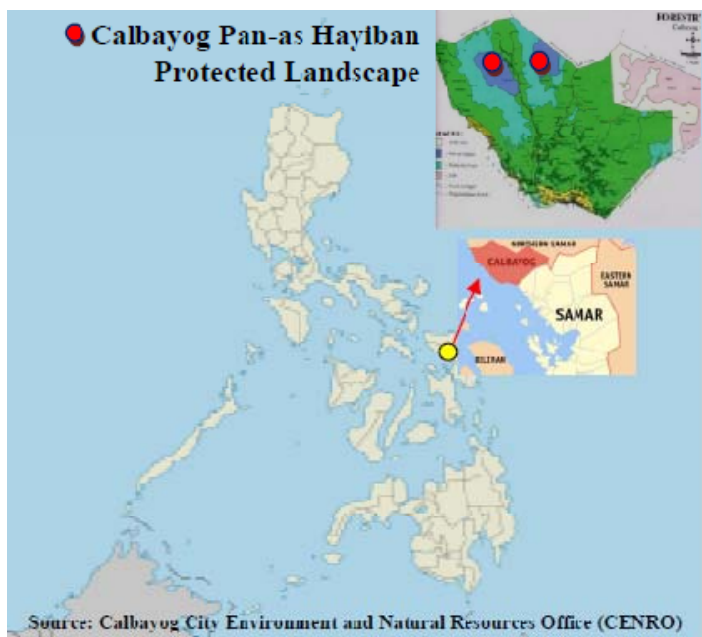

Study site was the Calbayog Pan-as Hayiban Protected Landscape (CPHPL) and its five upland communities of the forest watershed area such as SitioPeńa 2, Canggomaod, Danao 2, San Rufino and Cag-anahaw. The site has a geographical coordinates between $125^{\circ} 25^{\prime} 00^{\prime \prime}$ longitude and $12^{0} 13^{\prime} 00^{\prime \prime}$ latitude. CPHPL is a mid-mountain forest habitat with its highest elevation of 690 meters and the lowest 100 meters above the sea level. The area contains two (2) ecosystem types, the terrestrial ecosystem and freshwater ecosystem.

\section{Results/Findings}

Demographic, Household Profiles of the Respondents and their Land-use Practices

Majority of the respondents (Table 1) were 61 years old and above $(17.8 \%)$, female $(76.4 \%)$, married $(53.1 \%)$, and were elementary level (57\%) only. Same observations were made by Dolom (2003) that most of the respondents were primary level only and most were married. However, in contrast to Dolom (2003), and Wahab and Adewumi, and Ojo (2014), male participated actively in the CBFM. In terms of the household profiles majority of the family has income below P 5,000 only (89.9\%), with household members of 5-6 members (33\%), their nature of employment was self-employed $(43.7 \%)$ and primarily farming $(66.5 \%)$ was the source of income of their household heads. This has similar results with the study of Harrison (2006), Wahab, et. al (2003). Most were not recipient of 4Ps (53.6\%) and only $46.4 \%$ were members. Results implied that household had medium family size and farming $(47.10 \%)$ was their means of livelihood. Moreover, farming $(47.10 \%)$ was the primary source of living of the people and selling of timber products $(22.57 \%)$ were the second in the livelihood activities of the upland communities. This indicates that some community people engaged in logging of the forest trees.

Table 1 Demographic and Household Profiles of the Respondents

\begin{tabular}{|l|l|c|c|}
\hline \multicolumn{1}{|c|}{ Variables } & \multicolumn{1}{c|}{ Categories } & Frequency & Percentage \\
\hline Age & 61 years old and above & 55 & 17.8 \\
\hline Sex & Female & 236 & 76.4 \\
\hline Civil Status & Married & 164 & 53.1 \\
\hline Education & Elementary Level Only & 175 & 57 \\
\hline Family Income & Below - 5,000 & 276 & 89.9 \\
\hline Number of Household Members & $5-6$ members & 102 & 33 \\
\hline Nature of Employment & Firewood & 226 & 75.6 \\
\hline Household Head Occupation & Farming & 206 & 66.5 \\
\hline Additional Source of Income & No & 260 & 84.4 \\
\hline $\begin{array}{l}\text { Additional Source of Income from } \\
\text { the Government (4Ps Program) }\end{array}$ & None & 165 & 53.6 \\
\hline
\end{tabular}


Table 2. Livelihood Activities of the Upland Communities

\begin{tabular}{|l|c|c|}
\hline \multicolumn{1}{|c|}{ Livelihood Activities } & Frequency & Percent \\
\hline Farming & 146 & 47.10 \\
\hline Selling of Timber Products & 70 & 22.57 \\
\hline Sari-sari Store & 45 & 14.52 \\
\hline Livestock & 25 & 8.06 \\
\hline $\begin{array}{l}\text { Selling of Non-timber } \\
\text { Products }\end{array}$ & 9 & 2.90 \\
\hline Hunting & 4 & 1.29 \\
\hline Fishing & 2 & 0.65 \\
\hline Beekeeping & 2 & 0.65 \\
\hline Others & 7 & 2.26 \\
\hline TOTAL & $\mathbf{3 1 0}$ & $\mathbf{1 0 0 . 0 0}$ \\
\hline
\end{tabular}

The water source used were derived from falls/springs (51.9\%); connected with SAMELCO to generate their electricity, and source of fuel in cooking was the firewood (75.6\%). Harrison (2006) has same result that households obtained their fuel wood from the forest (Table 3). This means that the upland communities where dependent so much to the resources of the forests. Aside from this, they responded that their major resources used from the forest watershed area were food (12.3\%), timber for construction of houses $(9.8 \%)$, water for domestic uses (9.4\%) and fuel wood (9.4\%). It implies that upland communities obtained their basic needs from the forest (Table 4).

Table 3. Profiles on the Sources of Water, Electricity and Fuel of the Upland Communities

\begin{tabular}{|l|l|l|l|}
\hline Variables & Categories & Frequency & Percentage \\
\hline Source of Water & Forest Reserved (falls/springs) & 160 & 51.9 \\
\hline Source of Electricity & SAMELCO & 216 & 70.1 \\
\hline Source of Fuel & Firewood & 226 & 75.6 \\
\hline
\end{tabular}

Table 4. Resources Used of the Communities in the CPHPL

\begin{tabular}{|l|l|l|l|}
\hline Resources and Use of the Watershed & N & Percent & Percent of Cases \\
\hline Food & 189 & $12.3 \%$ & $64.9 \%$ \\
\hline Timber for construction & 151 & $9.8 \%$ & $51.9 \%$ \\
\hline Water for domestic uses & 145 & $9.4 \%$ & $49.8 \%$ \\
\hline Fuel wood & 140 & $9.1 \%$ & $48.1 \%$ \\
\hline Grass and Poles for housing materials & 101 & $6.5 \%$ & $34.7 \%$ \\
\hline Medicinal plants & 97 & $6.3 \%$ & $33.3 \%$ \\
\hline Irrigation water & 74 & $4.8 \%$ & $25.4 \%$ \\
\hline Others & 27 & $1.8 \%$ & $9.3 \%$ \\
\hline
\end{tabular}

Note: Multiple Responses

On the other hand, the major land-use types employed by the upland communities in the CPHPL were vegetable cropping (29.6\%), coconut planting (29.4\%), intercropping (13.5\%), and slash-and-burn farming (10.7\%). Carig (2012) had the same result with the present study (Table 5). It means that the upland communities utilized the forestland into vegetable gardening which urged them to engage to slash-and-burn system of farming. This shows that CPHPL were somehow degraded due to these activities.

Table 5. Land-Use Type of the Calbayog Pan-as Hayiban Protected Landscape

\begin{tabular}{|l|l|l|l|}
\hline Land-use Type & N & Percent & Percent of Cases \\
\hline Vegetable Cropping & 191 & $29.6 \%$ & $67.7 \%$ \\
\hline
\end{tabular}


South American Journal of Management

Special Edition 2016

\begin{tabular}{|l|l|l|l|}
\hline Coconut Planting/Area (copra) & 190 & $29.4 \%$ & $67.4 \%$ \\
\hline Intercropping & 87 & $13.5 \%$ & $30.9 \%$ \\
\hline Slash-and-burn Farming & 69 & $10.7 \%$ & $24.5 \%$ \\
\hline Rice Cropping & 51 & $7.9 \%$ & $18.1 \%$ \\
\hline Recreation & 18 & $2.8 \%$ & $6.4 \%$ \\
\hline Grassland/Pasture & 13 & $2.0 \%$ & $4.6 \%$ \\
\hline Agro-industrial & 10 & $1.5 \%$ & $3.5 \%$ \\
\hline Mining/Quarrying & 6 & $.9 \%$ & $2.1 \%$ \\
\hline Others & 11 & $1.7 \%$ & $3.9 \%$ \\
\hline
\end{tabular}

Note: Multiple responses

Level of Awareness of Watershed and the Current Watershed Protection and Conservation Practices

A majority of the respondents had "high awareness" on the nature and importance of the watersheds and of the CPHPL (Table 6) while most of them have "moderate awareness" on the protection and conservation practices of the watersheds (Table 7). This means that the upland communities were highly aware on the nature and importance of the watershed to environment and humans. However, in terms of the protection and conservation current practices, they have only moderately awareness on it. It means that they have knowledge and know-how in protecting and conserving of the watersheds but they were not practicing it due to their activities that contribute to the destruction of the watersheds condition. It further implies that the upland communities had an understanding of the community-based forest management program such as National Greening Program and Watershed Rehabilitation Project however; they don't have full support to the programs due to their livelihood activities that hindered them to give their utmost support to the programs of the CBFM.

Based on the interview, among the five upland communities, there were only two (2) people's organizations that were active: the CBFM projects implemented by the LGU, CENRO and PENRO, the Knights of Rizal Agricultural Endeavor Foundation, Inc of Sito Pena 2 and the Cag-anahaw Upland Farmers Association of Brgy. Cag-anahaw.

Table 6. Awareness Level on Watershed and of the Calbayog Pan-as Hayiban Protected Landscape (CPHPL)

\begin{tabular}{|l|c|c|c|c|}
\hline \multirow{2}{*}{ Statements } & \multicolumn{2}{|c|}{$\begin{array}{c}\text { Moderately } \\
\text { Aware }\end{array}$} & \multicolumn{2}{|c|}{$\begin{array}{c}\text { Highly } \\
\text { Aware }\end{array}$} \\
\cline { 2 - 5 } & f & \% & f & \% \\
\hline $\begin{array}{l}\text { a. Calbayog Pan-as Hayiban Protected Landscape } \\
\text { (CPHPL) is a forest reserved watershed area. }\end{array}$ & 79 & 25.5 & 120 & 38.7 \\
\hline $\begin{array}{l}\text { b. Calbayog Pan-as Hayiban Protected Landscape } \\
\text { (CPHPL) is a water catchment basin of Calbayog City } \\
\text { and its nearby municipalities. }\end{array}$ & 79 & 25.5 & 119 & 38.4 \\
\hline $\begin{array}{l}\text { c. Calbayog Pan-as Hayiban Protected Landscape } \\
\text { (CPHPL) is the main water source of Calbayog City } \\
\text { Water District (CCWD) and of the concessionaires in } \\
\text { Calbayog City. }\end{array}$ & 84 & 27.1 & 106 & 34.2 \\
\hline $\begin{array}{l}\text { d. Calbayog Pan-as Hayiban Protected Landscape } \\
\text { (CPHPL) is being protected by the community } \\
\text { people, CENRO and LGU. }\end{array}$ & 97 & 31.3 & 109 & 35.2 \\
\hline $\begin{array}{l}\text { e. Watershed supplies waster into the rivers, streams, } \\
\text { falls and other tributaries. }\end{array}$ & 96 & 31.0 & 129 & 41.6 \\
\hline $\begin{array}{l}\text { f. Watershed is covered with trees, forest and with } \\
\text { rich biodiversity. }\end{array}$ & 102 & 32.9 & 115 & 37.1 \\
\hline
\end{tabular}




\begin{tabular}{|l|c|c|c|c|}
\hline $\begin{array}{l}\text { g. Watershed provides livelihood opportunities to } \\
\text { community people living within its range. }\end{array}$ & 104 & 33.5 & 96 & 31.0 \\
\hline $\begin{array}{l}\text { h. Watershed helps maintain the balance of nature of } \\
\text { the ecosystem. }\end{array}$ & 101 & 32.6 & 91 & 29.4 \\
\hline $\begin{array}{l}\text { i. Watershed provides amenities and beautiful scenery } \\
\text { to local people and tourists. }\end{array}$ & 117 & 37.7 & 84 & 27.1 \\
\hline $\begin{array}{l}\text { j. Watershed helps prevent soil erosion, landslide, } \\
\text { flash floods and others calamities. }\end{array}$ & 83 & 26.8 & 135 & 43.5 \\
\hline
\end{tabular}

Table 7. Awareness Level on the Current Watershed Protection and Conservation Practices

\begin{tabular}{|c|c|c|c|c|}
\hline \multirow[t]{2}{*}{ Statements } & \multicolumn{2}{|c|}{$\begin{array}{l}\text { Moderately } \\
\text { Aware }\end{array}$} & \multicolumn{2}{|c|}{$\begin{array}{l}\text { Highly } \\
\text { Aware }\end{array}$} \\
\hline & f & $\%$ & f & $\%$ \\
\hline $\begin{array}{l}\text { a. Community people involves in the tree planting } \\
\text { activities or reforestation program. }\end{array}$ & 93 & 30.0 & 134 & 43.2 \\
\hline $\begin{array}{l}\text { b. Community people reports to the authority } \\
\text { individuals engaging the illegal logging in the } \\
\text { watershed area. }\end{array}$ & 100 & 32.3 & 116 & 37.4 \\
\hline $\begin{array}{l}\text { c. There are enough forest guards protecting the } \\
\text { watershed area. }\end{array}$ & 99 & 31.9 & 106 & 34.2 \\
\hline $\begin{array}{l}\text { d. There are nursery house/seedlings of trees cared } \\
\text { by the community people which are ready for } \\
\text { planting activities. }\end{array}$ & 93 & 30.0 & 104 & 33.5 \\
\hline $\begin{array}{l}\text { e. There are programs /activities on Educational } \\
\text { and Information Campaign (EIC) for Watershed } \\
\text { Management and Protection conducted in the } \\
\text { community. }\end{array}$ & 110 & 35.5 & 90 & 29.0 \\
\hline $\begin{array}{l}\text { f. Community people actively participate in the } \\
\text { Educational and Information Campaign (EIC) for } \\
\text { Watershed Management and Protection } \\
\text { Programs/Activities. }\end{array}$ & 115 & 37.1 & 84 & 27.1 \\
\hline $\begin{array}{l}\text { g. There is a functional community-based forest } \\
\text { management program in the area. }\end{array}$ & 103 & 33.2 & 81 & 26.1 \\
\hline $\begin{array}{l}\text { h. Community people discourage or do not } \\
\text { practice slash-and-burn farming (kaingin) system } \\
\text { that destroys the watershed condition. }\end{array}$ & 102 & 32.9 & 84 & 27.1 \\
\hline $\begin{array}{l}\text { i. Community people discourage or do not practice } \\
\text { quarrying in the watershed area that destroys the } \\
\text { watershed condition. }\end{array}$ & 109 & 35.2 & 85 & 27.4 \\
\hline $\begin{array}{l}\text { j. Community people and children value most the } \\
\text { importance of watershed forest reserved area and } \\
\text { avoid activities that destruct the watershed. }\end{array}$ & 107 & 34.5 & 94 & 30.3 \\
\hline
\end{tabular}

\section{Relationship of the Respondents' Profile to their Level of Awareness of Watershed} and to their Current Watershed Protection and Conservation Practices

Most of the items that assessed the awareness level on the watershed had shown no significant relationships to their age, sex, civil status, education, income and household members. Except for the items, "CPHPL is being protected by the community people, CENRO, PENRO and LGU" has a significant relationship to age and "CPHPL is a forest watershed reserved area" has significant relationship to civil status. This means that most of them who were living for a long time in their communities are knowledgeable and so much 
South American Journal of Management

Special Edition 2016

aware that CPHPL is a protected area and married couples have high awareness that CPHPL is a forest reserved area. However, in general the profiles of the respondents have no correlation to their awareness level on watershed and of the CPHPL. As to the relationship between the awareness on the current protection and conservation practices of the respondents and to their profile, result revealed that there were no significant relationships. However, the last item (j) had shown significant relationship to civil status. It implies that profile of the respondents has no direct association to their practices. Furthermore, the result divulged that everyone is encouraged to participate in the protection and conservation practices of the watersheds for its sustainability.

Accordingly, the variables involved in this study were somehow similar to other working variables used by Harrison (2006) and Wahab, et. al (2014), which suggested that socioeconomic, livelihood activities, land-use types, and community background were essential information for the preparation of forest watershed reserved areas management program/plan.

Table 8. Relationship Between Profile and their Level of Awareness on Watershed

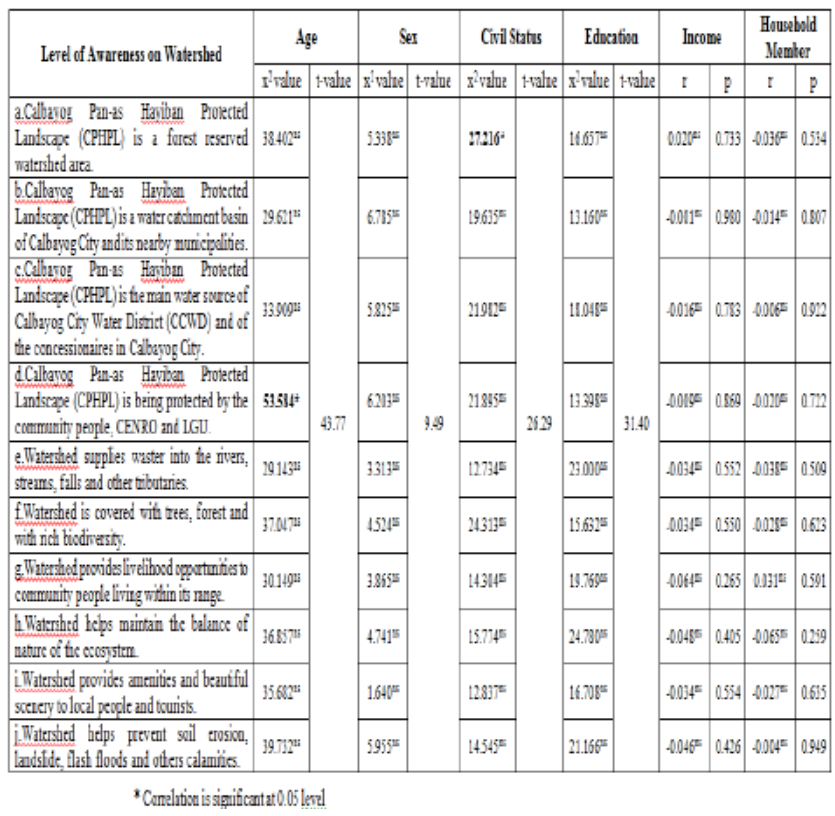

Table 9. Relationship between Profile and their Level of Awareness on Watershed

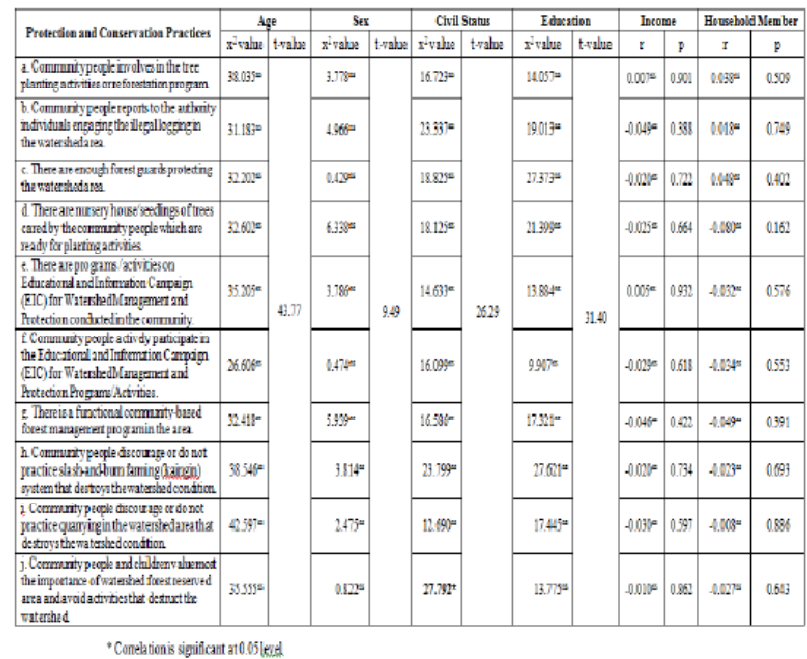




\section{Discussion/Conclusion}

\section{Summary of Findings}

Most of the respondents were female and from group of the senior citizens, married and had obtained an elementary level of education. Most of them belong to poverty line for having an income of below P 5,000, having 5-6 family members in every household, farming was the main source of income and livelihood. It also revealed that the basic needs such as water, fuelwoods, food, and timbers were taken from the forest. Major land-use types engaged by them was vegetable cropping that involved them in the slash-and-burn farming system.

In general, the result showed that the profiles of the respondents had no direct associations to their awareness level on watershed and of the CPHPL and to their protection and conservation practices. It means that whatever the status they have, it does not show any differences in the awareness level and protection and conservation of the watershed. It indicates that the upland communities should show our concern for the protection and conservation of the watershed and of our environment.

\section{Limitations}

This study explored only the five upland communities situated in the watershed forest reserved area of the locality. It measured the level of awareness of the community people on watershed and their current protection and conservation practices. Thus, it limits only on the assessment of the role of the community-based forest management on the awareness of watershed protection and conservation of the said study sites.

\section{Recommendations}

Thus, the researchers highly recommend that the government should strengthen the community-based forest management programs and collaborative partnership between the DENR, LGUs, POs and NGOs and institutions through capability building, community planning, and environmental education, and create an environment policy that would allow tenure community members to harvest planted trees in their farm. This is a way of encouraging local people to plant more trees because they know that they will benefit from it in the future. By and large, the government should provide community-based livelihoods other than agroforestry and reforestation projects to these communities.

\section{References}

[1.] Carig, E. T. (2012). Impact assessment of community-based forest management in the Philippines: A case study of CBFM in Nueva Viscaya. International Conference on Management and Social Sciences. 17-21.

[2.] Dolom, P. C. (2003). Criteria and indicators for assessing the sustainability of a community-based forest management project in the Philippines. Unasylva 214-215. Volume 54. 22-26.

[3.] Habtamu, T. (2011). Assessment of sustainable watershed management approach case study Lenche Dima, Tsegur Eyesus and Dijji watershed. Project Paper for Master of Professional Studies. Cornell University.

[4.] Harrison, P. (2006). Socio-economic study of forest-adjacent communities from Nyanganje forest to Udzungwa scarp: a potential wildlife corridor. Incorporating livelihood assessments and options for future management of Udzungwa forests. WWF-Tanzania Programme Office, Tanzania.

[5.] Postel, S. L. \& Thompson, B. H. Jr. (2005). Watershed protection: Capturing the benefits of nature's water supply services. National Resources Forum 29, 98-108.

[6.] Wahab, MKA, Adewumi, A.A., \& Ojo, SO. (2014). Assessment of socio-economic activities and sustainable rural development in Oba hill forest reserves, Osun State, Nigeria. E3 Journal of Environmental Research and Management, Volume 5(5),. Retrieved from http://wwwe3journals.org, November 2014. 
South American Journal of Management

Special Edition 2016

\section{Author Note}

Gerald T. Malabarbas, College of Arts and Sciences, Northwest Samar State University.

Novlloyd E. Celeste, College of Engineering and Technology, Northwest Samar State University.

This research was supported in part by a grant from the Office of the Research Services of the Northwest Samar State University.

Correspondence concerning this article should be addressed to Gerald T. Malabarbas, College of Arts and Sciences, Northwest Samar State University, Calbayog City, Samar, Philippines, 6710. E-mail: gmalabarbas@yahoo.com 